American Journal of Applied Sciences 7 (5): 640-646, 2010

ISSN 1546-9239

(C) 2010Science Publications

\title{
Comparative Effects of Drought and Salt Stress on Germination and Seedling Growth of Pennisetum divisum (Gmel.) Henr.
}

\author{
Wafa'a A. Al-Taisan \\ Department of Biology, Girls College of Science, University of Dammam, \\ P.O. Box 838, Dammam 31113, Saudi Arabia
}

\begin{abstract}
Problem statement: Water stress due to drought and salinity is probably the most significant abiotic factor limiting plant and also crop growth and development. Salinity and drought stresses are physiologically related, because both induce osmotic stress and most of the metabolic responses of the affected plants are similar to some extent. Water deficit affects the germination of seed and the growth of seedlings negatively. Temperature is an exceedingly important factor in seed germination. It directly affects whether a plant can sprout and, if so, how long it will take to emerge from the ground. Approach: The objective of this investigation was to determine the effect of four alternating temperature regime, drought and salt stress on germination characteristics of Pennisetum divisum. Seeds were germinated at four alternating temperatures $\left(10 / 20,15 / 25,20 / 35\right.$ and $25 / 40^{\circ} \mathrm{C}$ at $12 \mathrm{~h} \mathrm{light)}$. Seeds were also germinated with the iso-osmotic concentrations of sodium chloride $(\mathrm{NaCl})$ or in polyethylene glycol PEG8000 (0, -0.2, - $0.4,-0.6$ and $-0.8 \mathrm{MPa}$ ) for 14 days. Concentrations were applied to determine their effects on seed germination and seedling growth under laboratory conditions. The effects of different osmotic concentrations of $\mathrm{NaCl}$ and PEG were compared to distilled water (control). Results: Optimum germination was attained at $15 / 25^{\circ} \mathrm{C}$ which corresponds to temperatures prevailing during spring time. The highest values of germination parameters were obtained with no osmotic potential $(0 \mathrm{MPa})$ under $15 / 25^{\circ} \mathrm{C}$. The final germination percentage and rate of germination in the Pennisetum divisum treated seeds were decreased with the increase of the osmotic potential. At treatment by PEG, the germination was severely decreased at $-0.6 \mathrm{MPa}$. While, no germination occurred at- $0.8 \mathrm{MPa}$ by $\mathrm{NaCl}$. The results of the effects of the different osmotic potential of $\mathrm{NaCl}$ and PEG on the Radicle Length (RL) and the Hypocotyl Length (HL) mm of the tested $P$. divisum seeds were retarded when compared to the control. Conclusion: Results indicated germination sensitive to both the stresses. However, seedling growth was more sensitive to $\mathrm{NaCl}$ than was germination. However, seedling growth was more sensitive to $\mathrm{NaCl}$ than was germination responses to water stress induced by PEG and $\mathrm{NaCl}$. Results also indicated that seed germination of $P$. divisum is less sensitive to osmotic potential indicating that the seeds of the species are efficient in osmotically adjusting to soluble salts. This suggests the possibility of revegtating moderately salt affected soils.
\end{abstract}

Key words: Water potential, germination rate, Pennisetum divisum, polyethylene glycol, temperature

\section{INTRODUCTION}

Grasses play an important role in land stabilization and animal nutrition due to their protein, carbohydrates, fats, fibers and mineral contents, soil protection and sand dune fixation. Therefore, planting grasses constitutes an important part of any rangeland rehabilitation program. Pennisetum divisum (Gmel.)Henr. Gramineae grasses with inflorescence a dense, spicate, panicle terminal, widely distributed and most drought resistant grasses of the Saudi desert in coastal sands and sands around rocky ground places. This is a useful grazing plant, much browsed by camels (Mandaville, 1990). Despite the importance of $P$. divisum, there is no available information on its autecology. Also, there is no available information browse production of the species. Plants are constantly confronted with various biotic and abiotic stress factors such as low or high temperature, salt, drought, flooding, heat, oxidative stress and heavy metal toxicity (Mahajan and Tuteja, 2005; Achuo et al., 2006; Jaleel et al., 2007). Water availability and temperature are important factors that determine whether or not dispersed seeds germinate. For the seeds to germinate, they must imbibe water under a favorable temperature. However, salts and other solutes in the medium cause osmotic 
inhibitory effects on the seed's water uptake and retard and/or suppress germination. One of the most important abiotic factors limiting plant germination and early seedling stages is water stress brought about by drought and salinity (Almansouri et al., 2001), which are widespread problems around the world (Soltani et al., 2006). Salinity and drought affect the plants in a similar way (Katerji et al., 2004). Reduced water potential is a common consequence of both salinity and drought (Legocka and Kluk, 2005). Water stress acts by decreasing the percentage and rate of germination and seedling growth. $\mathrm{NaCl}$ and Polyethylene Glycol (PEG) compounds have been used to simulate osmotic stress effects in Petri dish (in vitro) for plants to maintain uniform water potential throughout the experimental period (Misra and Dwivedi, 2004).

Among the stages of the plant life cycle, seed germination and seedling emergence and establishment are key processes in the survival and growth of plants (Hadas, 2004). Seed germination and early seedling growth are critical stages for the establishment of plant populations under saline conditions (Perez et al., 1998; Khan and Gulzar, 2003). Grasses differ in their upper limit of salinity tolerance and an increase in salinity concentration usually delays and reduces seed germination (Gulzar et al., 2001). Seed germination under saline conditions occurs after high precipitation where soil salinity is usually reduced due to leaching (Khan and Ungar, 1986). The degree to which salinity affects germination by an osmotic effect or a specific ion toxicity and whether salt tolerance varies in different species is still a subject of study. Solutions of high molecular weight polyethylene glycol are often used to control water potential in seed germination studies.

Solutions of high molecular weight polyethylene glycol are often used to control water potential in seed germination studies (Hardegree and Emmerich, 1990). The PEG-induced inhibition of germination has been attributed to osmotic stress (Dodd and Donovan, 1999; Sidari et al., 2008). Temperature plays a crucial role in many biological and physiological processes of plants (Al-Ahmadi and Kafi, 2007; Berti and Johnson, 2008). The temperature changes have major impact on a number of processes which regulate seed germinability, including membrane permeability and the activity of membrane-bound as well as cytosolic enzymes (Tlig et al., 2008) and its interaction with the variable soil water content in the surface layers of the soil. Salinity-temperature interaction, in particular, determines seed germination pattern in many saltaffected environments (Al-Khateeb, 2006; Song et al., 2006).
Plants have evolved various biochemical and physiological mechanisms to combat water stress (Sakamoto and Murata, 2002; Sadeghian and Yavari, 2004). One such mechanism that is ubiquitous in plants is the accumulation of certain organic metabolites of lower molecular weight especially during seed germination and early stages of growth (Bewley and Black, 1994). The aim of this study is to investigate the effects of osmotic stress generated by $\mathrm{NaCl}$ or PEG and combined effects of these stress factors with temperature on germination characteristics and seedling growth of Pennisetum divisum.

\section{MATERIALS AND METHODS}

Seeds of $P$. divisum were collected during April, 2009, from naturally growing stands in the sandy soil near Al-Jubail on coast of the Arabian Gulf of Saudi Arabia. Seeds were separated from inflorescences and stored dry at $4^{\circ} \mathrm{C}$., During September 2009, stored seeds were sterilized with $0.5 \%$ sodium hypochlorite solution for $1 \mathrm{~min}$. Thereafter, they were washed twice with distilled water.

Effect of temperature: Seeds were germinated on double-layered with Whatman No. 1 filter papers placed in $10 \mathrm{~cm}$ diameter plastic dishes. All of the Petri dishes were kept in dark incubators maintained at room temperature at four alternating night and day temperature regime $\left(10 / 20,15 / 25,20 / 30\right.$ and $\left.25 / 40^{\circ} \mathrm{C}\right)$ representing the seasonal common temperatures prevailing in some selected meteorological stations in Eastern Saudi Arabia. Twenty-five seeds were germinated. The filter papers were moistened daily with the of distilled water.

Effect of water potential: Seeds of $P$. divisum were germinated at $15 / 25^{\circ} \mathrm{C}$. Seeds were submitted to germination using osmotic potentials $(0,-0.2,-0.4,-0.6$ and $-0.8 \mathrm{MPa})$ of sodium chloride $(\mathrm{NaCl})$ and Polyethylene Glycol (PEG) 8000 solutions according to (Michel, 1983). Twenty-five seeds were germinated on double-layered with Whatman No. 1 filter papers placed in $10 \mathrm{~cm}$ diameter plastic dishes. The filter papers were moistened daily with the five different concentrations of the extracts used. Control experiments whose filter papers were moistened with distilled water were set (25 seeds each). Each experiment was replicated four times. All Petri dishes were kept in dark incubators maintained at room temperature at $15 / 25^{\circ} \mathrm{C}$. Germination was monitored daily. The germinated seeds were recorded every day for a period of 14 days after sowing. Seeds were 
considered germinated when the radicle had protruded $2 \mathrm{~mm}$ through the seed coat. After 14 days of incubation, germination was expressed as the Final Percentage of Germination (FG\%) and Rate of Germination (GR) was calculated by (seeds day $^{-1}$ ) according to the method of Maguire's equation (Pezzani and Montana, 2006), the Radicle Length (RL), the Hypocotyl Length (HL).

Statistical analysis: Data were subjected to Analysis Of Variance (ANOVA), according to Gomez and Gomez (1984). Averages of the main effects and their interactions were compared using the revised Least Significant Difference test (LSD) at 0.05 level of probability. Computations and statistical analysis were done using SAS .

\section{RESULTS}

Germination: The germination percentage of seeds at different alternating temperature is shown in Fig. 1. The germination percentages increased with rise of temperature attaining their maximum at $15 / 25^{\circ} \mathrm{C}$ being lower at $25 / 40^{\circ} \mathrm{C}(80-30 \%)$ respectively (Table 1$)$. Incubation temperature of $10 / 25^{\circ} \mathrm{C}$ was suitable for germination of $P$. divisum and was followed by 20/35. Seed germination was significantly lower under extreme temperatures of $10-20$ and $20-35^{\circ} \mathrm{C}$ with no significant difference noticed between them (Fig. 1). Germination in the control commenced on day 2 under $15 / 25^{\circ} \mathrm{C}$ and on day 4 with higher temperatures at $25 / 40^{\circ} \mathrm{C}$. Germination percentage decreased significantly $(\mathrm{p}<0.0001)$ by increasing the osmotic potential of $\mathrm{NaCl}$ and PEG MPa especially at (-0.6 and $-0.8 \mathrm{MPa}$ ). The germination percentages attaining their maximum at treatment $\mathrm{NaCl}$ and PEG at -0.2 , was reached $58-73 \%$ respectively, the germination was severely decreased at $-0.6 \mathrm{MPa}$ reached $12-35 \%$ respectively, while under $-0.8 \mathrm{MPa}$ of $\mathrm{NaCl}$ and PEG was reached $0-10 \%$ respectively (Table 2). Germination treatment under $\mathrm{NaCl}$ and PEG -0.2,-0.6 MPa commenced on day 2 . The germination was delayed for 2,3 day under PEG -0.6 and -0.8 MPa respectively. At treatments by $\mathrm{NaCl}$, no germination occurred at $-0.8 \mathrm{MPa}$ and germination was very low at $-0.6 \mathrm{MPa}$ reached $12 \%$. Highest germination rates were observed at temperatures of $20 / 30$ and $15 / 25^{\circ} \mathrm{C}$. Lowest germination rate occurred under $25 / 40^{\circ} \mathrm{C}$. Although significant, GR differences were not substantial and ranged from 27.96-18.86 $\left(\% \mathrm{day}^{-1}\right)$ for distilled water at $15 / 25-25 / 40^{\circ} \mathrm{C}$ respectively Fig. 2 . The Rate of Germination (RG) of P. divisum under PEG was 28.94$19.66 \%$ day $^{-1}$ for -0.4 and -0.8 MPa respectively
(Table 2), while $\mathrm{NaCl}$ was $33.87-0.00$ day $^{-1}$ for -0.4 and $-0.8 \mathrm{MPa}$ respectively (Table 1 ). Increasing the solutions of PEG-8000 in the growth medium had a highly significant $(\mathrm{p}<0.0001)$ adverse effect on mean germination time in $P$. divisum lines. Interactions among all the factors were also statistically nonsignificant with respect to germination percentage (Table 1 and 2). Water deficit affects the germination of seed and the growth of seedlings negatively.

Seedling growth: Effect of the four different osmotic concentrations of $\mathrm{NaCl}$ and PEG 8000 on the Radicle Length (RL) $\mathrm{mm}$ of $P$. divisum is shown in Table 1 and 2. Significant $(p<0.0001)$ differences occurred in all observed germination characteristics in response to decreased matric potential (PEG osmotic solutions) (Table 2). In general, all measured germination characteristics deceased as water decease. The highest radical length was recorded in the control treatment it reached $61.60 \mathrm{~mm}$, then decreased by increasing osmotic potential of $\mathrm{NaCl}$ and PEG. The reduction in the RL at the $15 / 25^{\circ} \mathrm{C}$ under the moderate and highest osmotic potentials of $\mathrm{NaCl}(-0.2$ and $-0.8 \mathrm{MPa}$ ) varied between 33.40 and $0.00 \mathrm{~mm}$, while comparable osmotic potentials in the PEG the reduction varied between 49.40 and $3.60 \mathrm{~mm}$, respectively.

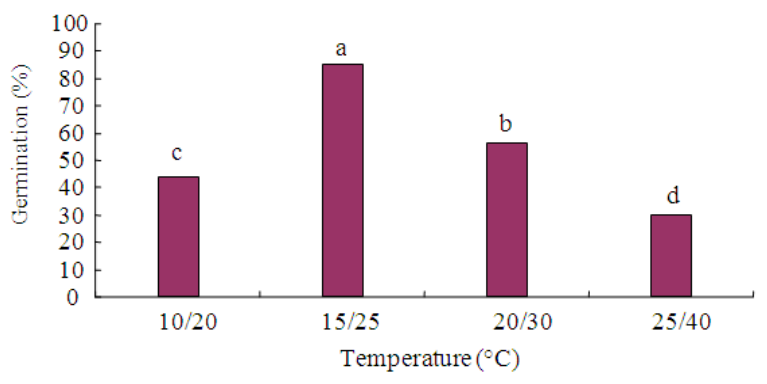

Fig. 1: Percentage of seed germination of P.divisum in response to four temperature regimes.

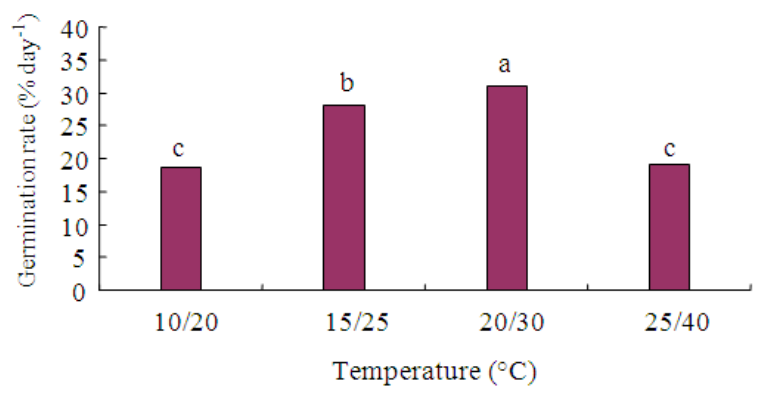

Fig. 2: Germination rate $\left(\% \mathrm{day}^{-1}\right)$ of $P$. divisum in response to four temperature regimes. 
Am. J. Applied Sci., 7 (5): 640-646, 2010

Table 1: Effects of osmotic potential induced by sodium chloride NaCl MPa on seed germination of $P$. divisum.

\begin{tabular}{lllll}
\hline Osmotic potential (MPa) & Final germination (\%) & Germination rate $\left(\%\right.$ day $\left.^{-1}\right)$ & Radical length $(\mathrm{mm})$ & Hypocotyl length $(\mathrm{mm})$ \\
\hline 0 & $85.00^{\mathrm{a}}$ & $30.845^{\mathrm{a}}$ & $61.600^{\mathrm{a}}$ & $50.600^{\mathrm{a}}$ \\
-0.2 & $58.00^{\mathrm{a}}$ & $29.4525^{\mathrm{b}}$ & $33.400^{\mathrm{b}}$ & $30.200^{\mathrm{b}}$ \\
-0.4 & $41.00^{\mathrm{b}}$ & $33.8775^{\mathrm{a}}$ & $22.200^{\mathrm{bc}}$ & $16.000^{\mathrm{c}}$ \\
-0.6 & $12.00^{\mathrm{c}}$ & $24.8725^{\mathrm{c}}$ & $5.400^{\mathrm{cd}}$ & $3.600^{\mathrm{d}}$ \\
-0.8 & $0.00^{\mathrm{d}}$ & $0.0000^{\mathrm{d}}$ & $0.000^{\mathrm{d}}$ & $0.000^{\mathrm{e}}$ \\
\hline
\end{tabular}

Table 2: Effects of osmotic potential induced by polyethylene glycol PEG8000 MPa on seed germination of P.divisum.

\begin{tabular}{lllcc}
\hline Osmotic potential $(\mathrm{MPa})$ & Final germination $(\%)$ & Germination rate $\left(\%\right.$ day $\left.^{-1}\right)$ & Radical length $(\mathrm{mm})$ & Hypocotyl length $(\mathrm{mm})$ \\
\hline 0 & $85^{\mathrm{a}}$ & $30.845^{\mathrm{a}}$ & $61.600^{\mathrm{a}}$ & $50.600^{\mathrm{a}}$ \\
-0.2 & $73^{\mathrm{a}}$ & $29.810^{\mathrm{a}}$ & $49.400^{\mathrm{a}}$ & $41.200^{\mathrm{a}}$ \\
-0.4 & $60^{\mathrm{b}}$ & $28.948^{\mathrm{b}}$ & $27.400^{\mathrm{b}}$ & $17.400^{\mathrm{c}}$ \\
-0.6 & $35^{\mathrm{c}}$ & $22.083^{\mathrm{c}}$ & $8.600^{\mathrm{c}}$ & $5.600^{\mathrm{d}}$ \\
-0.8 & $10^{\mathrm{d}}$ & $19.665^{\mathrm{d}}$ & $3.600^{\mathrm{c}}$ & $2.800^{\mathrm{d}}$ \\
\hline
\end{tabular}

The results of the effects of different osmotic potential of $\mathrm{NaCl}$ and PEG on the Hypocotyl Length (HL) $\mathrm{mm}$ of the tested $P$. divisum are shown in Table 1 and 2. It revealed that the growths of $P$. divisum in the different osmotic potential of $\mathrm{NaCl}$ and PEG seeds were retarded when compared to the control. The degree of retardation increased with the increase in the osmotic potential of $\mathrm{NaCl}$ and PEG. The highest growth appeared at the control treatment reaching $50.60 \mathrm{~mm}$ The hypocotyl length was severely decreased of $\mathrm{NaCl}$ at 0.4,-0.6 MPa reached 16.0-3.60 $\mathrm{mm}$ respectively, while under -0.4,-0.6 MPa of PEG was reached 17.40$5.60 \mathrm{~mm}$ respectively. No growth of the HL was obtained of $P$. divisum at $-0.8 \mathrm{MPa}$ of $\mathrm{NaCl}$ (Table 1 and 2).

\section{DISCUSSION}

In this study, noticeable from Fig. 1 and 2 that significant differences existed in germination percentage among incubation temperatures. When seeds were moistened with deionized water of $P$. divisum showed a high percentage of germination over a wide temperature range. These results indicate that seeds of this specie in germinable in Saudi Arabia desert regions at any time between mid-spring to mid-autumn. When treatment by germination $\mathrm{NaCl}$ and PEG 8000, the germination percentage of $P$. divisum decreased significantly $(p<0.0001)$ by increasing the osmotic potential, germination was very low at -0.6 and $-0.8 \mathrm{MPa}$ osmotic potential and no germination occurred at $-0.8 \mathrm{MPa}$ of $\mathrm{NaCl}$ ). P. divisum showed highest values of germination at osmotic potential zero, they were more sensible than PEG to salt imposed water deficit. However, the results obtained with $\mathrm{NaCl}$ did not match with the one observed for PEG and $\mathrm{NaCl}$ has higher effect than PEG, meaning that there was another factor acting in this case. According to Mayer and PoljakoffMayber (1989) results like this could be attributed to absence of energy to start the germination process, as energy was obtained by increments in the respiratory pathway after the ambition and in low levels of water potential tax water absorption was processed slowly. Reduction in germination by an increase of salinity levels has been described by numerous authors (Breen et al., 1977; Ungar, 1982; El-Tayeb, 2005; Azhdari et al., 2010).

The inhibitory effects of $\mathrm{NaCl}$ on seed germination could be due to its direct affect on the growth of the embryo. Poljakoff-Mayber et al. (1994) found that the elongation of the embryonic axis of Kosteletzkya virginica was strongly inhibited by high levels of $\mathrm{NaCl}$ in irrigation solutions. Alternatively, $\mathrm{NaCl}$ may also increase the osmotic potential of the media causing inhibitory effects on seed imbibition (Almansouri et al., 2001). There was significance $(\mathrm{p}<0.0001)$ the interaction between $P$. divisum and $\mathrm{NaCl}$ induced water deficit, which led to reduction of shoot and root length, especially at -0.6 and $-0.8 \mathrm{MPa}$. According to (Tobe et al., 2001). When seeds were moistened with $-5.0 \mathrm{MPa} \mathrm{NaCl}$ solution for 5 days, the seeds of three species completely lost their germinability. $\mathrm{NaCl}$ may be inhibitory to the activities of some enzymes that may play critical roles in seed germination.

For all treatments, $\mathrm{NaCl}$ was found to be more decrease to water uptake, especially at high concentrations, than iso-osmotic solutions of PEG. The first phase of water uptake by the seeds involves movement of water into the free space (apoplast) and does not depend on the osmotic potential of the surrounding solution (Bewley and Black, 1994). The second slower linear phase of water uptake involves the movement of water across cell membranes into the cells of the seeds and is determined by the difference between the osmotic potential of the seed and that of the medium (Bewley and Black, 1994). 
The final germination percentage and rate of germination in the $P$. divisum -treated seeds were decreased with the increase of the osmotic potential, but this reduction in $\mathrm{NaCl}$ treatment were higher than PEG treatment. Similar results were found in Salsola villosa by Assaeed (2001) Mohammadkhani and Heidari (2008) in two Maize cultivars and Al-Taisan et al. (2010) in Ephedra alata. Differences in GR, followed a similar pattern of total germination percentage. Germination Rate (GR) also varied significantly $(p<0.0001)$ with temperature treatments. The decrease of GR was stronger at different levels of the $\mathrm{NaCl}$ and PEG solutions compared to the FG percentage. This result corroborates other studies showing that osmotic stress primarily reduces rate of germination rather than germination percentage (Kaya et al., 2008). It is assumed that germination rate and the final seed germination decrease with the decrease of the water movement into the seeds during imbibitions (Hilhorst, 1995). Salinity stress can affect seed germination through osmotic effects (Welbaum et al., 1990). Salt induced inhibition of seed germination could be attributed to osmotic stress or to specific ion toxicity (Faheed et al., 2005). Germination percentage also significantly decreased as the level of salinity of the medium increased (Mauromicale and Licandro, 2002). These results are similar in line with (BayueloJimenez et al., 2002). They found that the mean time to germination of almost all Phaseolus species increased with the addition of $\mathrm{NaCl}$ and this increase in was greater in higher concentration as compared to low concentration. The reduction in root and shoot development may be due to toxic effects of the $\mathrm{NaCl}$ used as well as unbalanced nutrient uptake by the seedlings. High salinity may inhibit root and shoot elongation due to slowing down the water uptake by the plant may be another reason for this decrease (Werner and Finkelstein, 1995).

The results of this study showed a greater reduction of HL and RL in comparison to germination phase with the increase of the osmotic potential with $\mathrm{NaCl}$ and PEG. This is in conformity with findings from Hosseini et al. (2002) in soybean and Kaya et al. (2008) in chickpea (Cicer arietinum L.) who observed that $\mathrm{NaCl}$ or PEG had greater inhibitory effects on seedling development than germination. Hosseini et al. (2002) suggested that cell division, which is a post-germination phenomenon responsible for seedling elongation and development, is more sensitive to the $\mathrm{NaCl}$ or PEG compared to cell expansion, which drives germination. Comparing the effect of both types of water potential, the present results indicate $P$. divisum seeds are efficient in osmotically adjusting to $\mathrm{NaCl}$ solutions. Ions may enter the seed, lowering its osmotic potential and thus facilitating hydration (Sharma, 1973).

\section{CONCLUSION}

In the germination and early seedling growth stages the investigated showed different responses to water stress induced by PEG and $\mathrm{NaCl}$. However, seedling growth was more sensitive to $\mathrm{NaCl}$ than was germination responses to water stress induced by PEG and $\mathrm{NaCl}$. However, seedling growth was more sensitive to $\mathrm{NaCl}$ than was germination. Results also indicated that seed germination of $P$. divisum is less sensitive to osmotic potential indicating that the seeds of the species are efficient in osmotically adjusting to soluble salts. This suggests the possibility of revegtating moderately salt affected soils. Further study is needed to study the effect of interaction among the three environmental conditions on germination and seedling growth and establishment of $P$. divisum. This suggests the possibility of revegtating moderately salt affected soils.

\section{REFERENCES}

Achuo, E.A., E. Prinseh and M. Hofte, 2006. Influence of drought, salt stress and abscisic acid on the resistance of tomato to Botrytis cinerea and Oidium neolycopersici. Plant Pathol., 55: 178-186. DOI: 10.1111/j.1365-3059.2006.01340.x

Al-Ahmadi, M.J. and M. Kafi, 2007. Cardinal temperatures for germination of Kochia scoparia (L.). J. Arid Environ., 68: 308-314. DOI: 10.1016/j.jaridenv.2006.05.006

Al-Khateeb, S.A., 2006. Effect of salinity and temperature on germination, growth and ion relations of Panicum turgidum forssk. Bioresour. Technol., $\quad$ 97: $292-298 . \quad$ DOI: 10.1016/j.biortech.2005.02.041

Almansouri, M., J.M. Kinet and S. Lutts, 2001. Effect of salt and osmotic stresses on germination in durum wheat (Triticum durum Desf.). Plant Soil, 231: 243-254. DOI: 10.1023/A:1010378409663

Al-Taisan, W.A., A.A. Al-Qarawi and M.S. Alsubiee, 2010. Effect of water stress by polyethylene glycol 8000 and sodium chloride on germination of Ephedra alata decne seeds. Saudi Journal of Biological Sciences, 17: 253-257. DOI: 10.1016/j.sjbs.2010.04.011.ON LINE

Assaeed, A.M., 2001. Effect of temperature and water potential on germination of Salsola villosa DEL. EX ROEM Et Schult. Assiut J. Agric. Sci., 32: 173-183. 
Azhdari, Gh., A. Tavili and M.A. Zare, 2010. Effects of various salts on the germination of two cultivars of Medicago sativa. Frontiers Agric. China, 4: 63-68. DOI: 10.1007/s11703-009-0078-y

Bayuelo-Jimenez, J.S., R. Craig and J.P. Lynch, 2002. Salinity tolerance of phaseolus species during germination and early seedling growth, Crop Sci., 42: 1584-1594. http://crop.scijournals.org/cgi/content/full/42/5/1584

Berti, M.T. and B.L. Johnson, 2008. Seed germination response of cuphea to temperature. Ind. Crops Prod., 27 : 17-21. DOI: 10.1016/j.indcrop.2007.05.004

Bewley, J.D. and M. Black, 1994. Seeds: Physiology of Development and Germination. 2nd Edn., Plenum Press, New York, ISBN: 0-306-44747-9, pp:445.

Breen, C. M., C. Everson and K. Rogers, 1977. Ecological studies on sporobolus virginicus (L.) kunth with particular reference to salinity and inundation. Hydrobiologia, 54: 135-140. DOI: 10.1007/BF00034987

Dodd, G.L. and L.A. Donovan, 1999. Water potential and ionic effects on germination and seedling growth of two cold desert shrubs. Am. J. Bot., 86: 1146-1153. PMID: 10449394

El-Tayeb, M. A., 2005. Response of barley grains to the interactive e.ect of salinity and salicylic acid. Plant Growth Regul. 45: 215-224. DOI: 10.1007/s10725005-4928-1

Faheed, F.A., A.M. Hassanein and M.M. Azooz, 2005. Gradual increase in $\mathrm{NaCl}$ concentration overcomes inhibition of seed germination due to salinity stress in Sorghum bicolor (L.). Acta Agron. Hungarica, 53: 229-239. DOI: 10.1556/AAgr.53.2005.2.11

Gomez, K.A. and A.A. Gomez, 1984. Statistical Procedures for Agricultural Research. 2nd Edn., Wiley- Interscience, USA., ISBN: 978-0-47187092-0, , pp:704.

Gulzar, S., M.A. Khan and I.A. Ungar, 2001. Effect of salinity and temperature on the germination of Urochondra setulosa. Seed Sci. Technol., 29: 21-29. http://www.halophyte.org/pdfs/drkhan_pdfs/23.pdf

Hosseini, M. K., A.A. Powell and I.J. Bingham, 2002. Comparison of the seed germination and early seedling growth of soybean in saline conditions. Seed Sci. Res., 12: 162-172. DOI: 10.1079/SSR2002108

Hadas, A., 2004. Seedbed Preparation: The Soil Physical Environment of Germinating Seeds. In: Handbook of Seed Physiology: Applications to Agriculture, Benech-Arnold, R.L. and R.A. Sanchez (Eds.). Food Product Press, New York, ISBN: 1560229292, pp: 3-49.
Hardegree, S.P. and W.E. Emmerich, 1990. Effect of polyethylene glycol exclusion on the water potential of solution-saturated filter paper. Plant Physiol., 92: 462-466. PMID: 16667298

Hilhorst, H.W.M., 1995. A critical update on seed dormancy. I. Primary dormancy1. Seed Sci. Res. 5: 61-73. DOI: $10.1017 /$ S0960258500002634

Jaleel, C.A., P. Manivannan, B. Sankar, A. Kishorekumar and R. Gopi, 2007. Water deficit stress mitigation by calcium chloride in Catharanthus roseus: Effects on oxidative stress, proline metabolism and indole alkaloid accumulation. Colloids Surf. B: Biointerf., 60: 110-116. PMID: 17643271

Katerji, N., J.W. Van Hoorn, A. Hamdy and M. Mastrorilli, 2004. Comparison of corn yield response to plant water stress caused by salinity and by drought. Agrcu. Water Manage., 65: 95-101. DOI: 10.1016/j.agwat.2003.08.001

Kaya, M., G. Kaya, M.D. Kaya, M. Atak and S. Saglam et al., 2008. Interaction between seed size and $\mathrm{NaCl}$ on germination and early seedling growth of some Turkish cultivars of chickpea (Cicer arietinum L.). J. Zhe. Univ. Sci., 9: 371377. DOI: 10.1631/jzus.B0720268

Khan, M.A. and I.A. Ungar, 1986. Life history and population dynamics of Atriplex triangularis. Plant Ecol., 66: 17-25. www.jstor.org/stable/20037293

Khan, M.A. and S. Gulzar, 2003. Germination responses of Sporobolus ioclados: A saline desert grass. J. Arid Environ., 53: 387-394. DOI: 10.1006/jare.2002.1045

Legocka, J. and A. Kluk, 2005. Effect of salt and osmotic stress on changes in polyamine content and arginine decarboxylase activity in Lupinus luteus seedlings. Plant Physiol., 162: 662-668. PMID: 16008088

Mahajan, S. and N. Tuteja, 2005. Cold, salinity and drought stresses: An overview. Arch. Biochem. Biophys., 444: 139-158. PMID: 16309626

Mandaville, J.P., 1990. Flora of Eastern Saudi Arabia. Kegan Paul International, London, York, ISBN: 10: 0710303718, pp: 482.

Mauromicale, G. and P. Licandro, 2002. Salinity and temperature effects on germination, emergence and seedling growth of globe artichoke. Agronomie, 22: 443-450. DOI: 10.1051/agro:2002011

Mayer, A.M. and A. Poljakoff-Mayber, 1989. The Germination of Seeds. 4th Edn., Pergamon Press, Oxford, UK., ISBN: 10: 0080357229, pp: 270.

Michel, B.E., 1983. Evaluation of the water potentials of solutions of polyethylene glycol 8000 both in the presence and absence of other solutes. Plant Physiol., $\quad 72$ : 66-70. http://www.plantphysiol.org/cgi/reprint/72/1/66.pdf 
Misra, N. and U.N. Dwivedi, 2004. Genotypic differences in salinity tolerance of green gram cultivars. Plant Sci., 166: 1135-1142. DOI: 10.1016/j.plantsci.2003.11.028

Mohammadkhani, N. and R. Heidari, 2008. Effects of drought stress on soluble proteins in two maize varieties. Turk. J. Bol., 32: 23-30. http://journals.tubitak.gov.tr/biology/issues/biy.../bi y-32-1-4-0706-3.pdf

Poljakoff-Mayber, A., G.F. Somers, E. Werker and J.L. Gallagher, 1994. Seeds of Kosteletzkya virginica (Malvaceae): Their structure, germination and salt tolerance. Germination and salt tolerance. Am. J. Bot., 81: 54-59. http://www.jstor.org/stable/2445562

Perez, T., C. Moreno, G.L. Seffino, A. Grunber, Bravo and Zenoff, 1998. Salinity effects on the early development stages of Panicum coloratum: Cultivar differences. Grass Forage Sci., 53: 270-278. DOI: 10.1046/j.1365-2494.1998.00139.x

Pezzani, F. and C. Montana, 2006. Inter-and intraspecific variation in the germination response to light quality and scarification in grasses growing in two-phase mosaics of the Chihuahuan desert. Ann. Bot., 97: 1063-1071. DOI: 10.1093/aob/mcl053

Sadeghian, S.Y. and N. Yavari, 2004. Effect of waterdeficit stress on germination and early seedling growth in sugar beet. J. Agron. Crop Sci., 190: 138-144. DOI: 10.1111/j.1439-037X.2004.00087.x

Sakamoto, A. and N. Murata, 2002. The role of glycine betaine in the protection of plants from stress: Clues from transgenic plants. Plant Cell Environ., 25: 163-171. PMID: 11841661

Sharma, M.L., 1973. Simulation of drought and its effect on germination of five pasture species. Agron. $\quad$ J., 65: 423-431. http://agron.scijournals.org/cgi/content/abstract/65/ 6/982

Sidari, M., C. Mallamaci and A. Muscolo, 2008. Drought, salinity and heat differently affect seed germination of Pinus pinea. J. For. Res., 13: 326-330. DOI: 10.1007/s10310-008-0086-4
Soltani, A., M. Gholipoor and E. Zeinali, 2006. Seed reserve utilization and seedling growth of wheat as affected by drought and salinity. Environ. Exp. Bot., 55: 195-200. DOI: 10.1016/j.envexpbot.2004.10.012

Song, J., G. Feng and F. Zhang, 2006. Salinity and temperature effects on germination for three saltresistant euhalophytes, Halostachys caspica, Kalidium foliatum and Halocnemum strobilaceum. Plant Soil, 279: 201-207. DOI: 10.1007/s11104005-1012-6

Tlig, T., M. Gorai and M. Neffati, 2008. Germination responses of Diplotaxis harra to temperature and salinity. Flora-Morphol. Distribut. Funct. Ecol. Plants, 203: 421-428. DOI: 10.1016/j.flora.2007.07.002

Tobe, K., L. Zhang, G.Y. Qiu, H. Shimizu and K. Omasa, 2001. Characteristics of seed germination in fivenon-halophytic Chinese desert shrub species J. Arid Enviro. 47: 191-201. DOI: 10.1006/jare.2000.0689

Ungar, I.A., 1982. Germination Ecology of Halophytes. In: Contributions of the Ecology of Halophytes. In: Sen, D.N. and K.S. Rajpurohits (Eds.). W. Junk Publishers, The Hague, pp: 143-154. DOI: 10.1007/BF02858320

Welbaum, G.E., T. Tissaoui and K.J. Bradford, 1990. Water relations of seed development and germination in muskmelon (Cucumis melo L.). III. Sensitivity of germination to water potential and abscisic acid during development. Plant Physiol., 92: 1029-1037. PMID: 16667367

Werner, J.E. and R.R. Finkelstein, 1995. Arabidopsis mutants with reduced response to $\mathrm{NaCl}$ and osmotic stress. Physiol. Plant, 93: 659-666. DOI: 10.1111/j.1399-3054.1995.tb05114.x 